\title{
Bemiparin Sodium
}

National Cancer Institute

\section{Source}

National Cancer Institute. Bemiparin Sodium. NCI Thesaurus. Code C53400.

The sodium salt of bemiparin, a second generation, synthetic, low-molecular-weight heparin (LMWH) with anticoagulant activity. Derived, after depolymerisation and fractionation, from medical-grade porcine unfractionated heparin (UFH), bemiparin has an average molecular weight of 3,600 daltons and has a higher anti-factor Xa/anti-factor Ila ratio (8:1) than first-generation LMWHs. This anticoagulant binds to antithrombin III, thereby enhancing the inactivation of activated factor X (Factor Xa) and, to a lesser extent, activated factor II (Factor IIa). Compared to unfractionated heparins, the use of bemiparin is associated with lower incidences of major bleeding, osteoporosis, and heparin-induced thrombocytopenia. Bemiparin also promotes a greater release of tissue factor pathway inhibitor than UFH or dalteparin. 